\title{
The Effect of Perception of Security, Easy of Transaction, and Shopping Experience on Purchase Decision and its Implications on Customers Satisfaction (Case Study of Geraipedia Jabodetabek Customers)
}

\author{
Melitina Tecoalu1) \\ melitina@ukrida.ac.id \\ Soegeng Wahyoedi2) \\ swahyoedi@ukrida.ac.id \\ Edwind Kustiawan*3) \\ edwindkustiawan@yahoo.com \\ 122)3)Krida Wacana Christian University, Jakarta \\ *) Corresponding Author :_edwindkustiawan@yahoo.com
}

\begin{abstract}
This study discusses the perception of security, ease of transaction, and ease of shopping for purchasing decisions, as well as the implications of purchasing decisions on Geraipedia customer satisfaction. This research discusses some of the problems that Geraipedia has experienced. The first problem is related to security, namely the leakage of Geraipedia user data circulating in the media. This has been acknowledged by Geraipedia, that it was true that 91 million customer data has been leaked. The data includes encrypted customer passwords, customer names, e-mail addresses, date of birth, and telephone numbers. Second, Geraipedia itself had a problem with an error payment system. Transactions made by customers are considered unsuccessful. However, the solutions provided by Geraipedia are unclear, not detailed, and unresponsive so that the customer shopping experience is not good. If the above problems are not resolved, then other problems arise related to transaction security, ease of transactions, and customer shopping experience. These problems will affect customer purchasing decisions on Geraipedia, so this customer purchase decision will affect Geraipedia customer satisfaction.

The first hypothesis in this study is the influence of security perceptions on purchasing decisions on Geraipedia. The results showed that the security perception variable had no effect on the purchasing decision variable with a t-statistic of 0.318 $<1.96$ and a significance value of $0.750>0.05$. The second hypothesis in this study is the effect of ease of transaction on purchasing decisions on Geraipedia. The results showed that the variable transaction ease had an effect on the purchasing decision variable with a t-statistic of 5.843> 1.96 and a significance value of $0.00<0.05$. The third hypothesis in this study is the influence of shopping experience on purchasing decisions on Geraipedia. The results showed that the shopping experience variable had a positive effect on the purchasing decision variable with a t-statistic of 7.898> 1.96 and a significance value of $0.00<0.05$. The fourth hypothesis in this study is the
\end{abstract}


influence of purchasing decisions on customer satisfaction in Geraipedia. The results showed that the purchasing decision variable had an influence on the customer satisfaction variable with a t-statistic of $12.197>1.96$, with a significance value of 0.00 $<0.05$.

Keywords: security perception, ease of transaction, shopping experience, purchase decision, and customer satisfaction. 


\section{PRELIMINARY}

In the current era, of course, the internet is no longer a foreign thing, on the contrary, the internet is a major necessity during a pandemic, because of the enormous role of the internet both in the world of work, schooling, and business. Because the internet can help all activities to keep going in this day and age. Work, school, and business no longer need to come to the office and school, just turn on a laptop or computer at home and be connected to the internet, then you will be directly connected online.

Geraipedia is a fast-growing E-commerce in Indonesia. Geraipedia has brought changes to the business sector, where once the business had to have a place, have employees, and had to meet in person for transactions, now it has developed into a virtual world with only a smartphone, all that can be done. Due to the ease of access via smartphones, more and more offline business entrepreneurs are turning to online businesses which make the online business competition even tighter, of course, online shops must think of strategies so that their online stores can survive and continue to grow.

Geraipedia is a major company in the world of e-commerce in Indonesia. Of course, Geraipedia's growth is very fast. Geraipedia has changed the conventional way of selling into a modern shop that can sell 24 hours a day. Of course, the success of Geraipedia is the problems that arise as a result of Geraipedia which is very detrimental to customers. One of the problems in Geraipedia is related to security, the leakage of Geraipedia user data circulating in the media, and this has been acknowledged by Geraipedia, 91 million customer data has indeed, the data includes encrypted customer passwords, name customers, email address, date of birth and telephone number (Source : Cnbcindonesia.com). As for Geraipedia's problems related to the convenience of the transaction system at Geraipedia, the transactions carried out must be simple and easy to use and not make it difficult for customers, so that customers will make purchasing decisions at Geraipedia. But if the transaction is not easy or difficult, it will make customers think again about buying. Geraipedia has a problem when running an error payment system, this Geraipedia transaction is considered a failure, and the solution provided by Geraipedia is not responsive in dealing with problems and provides unclear or unclear explanations. (Source : Detik.com).

The customer shopping experience regarding materials, images, products, colors, and designs does not match those in the photos posted on Geraipedia, so customers feel at a loss because the goods received are very disappointing. With good or bad experiences at Geraipedia customers can choose to shop on the Geraipedia application or other e-commerce applications. (Source: Digital subscribers) 
Customers have several considerations before finally deciding to buy, such as price, product reviews, safety, convenience, shopping experience, and others. In making a purchase decision, the customer will take further action, then after a successful purchase process is based on whether he is satisfied or not. This determines whether the customer is satisfied or not with the product purchased. Of course, this relates to customer expectations with the product received, if the product does not meet customer expectations, the customer feels dissatisfied, and vice versa, if the product provided is not following what the customer wants, of course, the customer feels disappointed or dissatisfied, and vice versa. if it is following the wishes of the customer, the customer is happy or satisfied. Customer satisfaction is the extent to which the perceived product performance meets buyer expectations (According to Kotler and Armstrong, 2018).

\section{LITERATURE REVIEW}

\section{Perception of Security}

According to Flavia'n and Guinalı'u (2006), the perception of security is a guarantee of confidentiality, integrity, authentication, and no recording of transactions. Confidentiality includes data that can be seen by someone who has authority. Integrity is an information system that refers to the impossibility of the data being stored, then it can be modified by a third party and does not ask for permission. Authentication is a limited activity that is carried out after identifying or having a guarantee, the identity is used for something special.

\section{Ease of transaction}

Ease of transaction is that an individual believes that when using technology they will be free from a business. Ease is the belief of an individual in using technology that can be easily used and understood (Tjini and Baridwan, 2011).

\section{Shopping Experience}

According to Kotler and Keller (2016), experience is learning that affects changes in a person's behavior including customer experience, information, transaction experiences.

There are six components contained in the customer experience according to Schmitt (2010), as follows:
1. Sensory
2. Emotional
3. Cognitive
4. Pragmatic
5. Lifestyle
6. Relational

The following are the benefits that customers get from improving the shopping experience, as follows:

1. Strengthening brand preferences

2. Reduce customer churn

3. Inspire customers to help the company

4. Increase profit 


\section{Purchase Decision}

Customer purchasing decisions are a major part of customer behavior that cannot be separated before deciding to use or not use the products offered by the company.

According to Assauri (2017), a purchase decision is an action taken to determine a purchase decision, which includes deciding what to buy or not, this decision is based on the results obtained from activities that have been carried out.

The stages in purchasing decisions according to Kotler and Keller (2016) are that purchasing decisions are made up of five stages. This means that the purchase decision is divided into five stages, as follows:

1. Introduction to the Problem

2. Information Search.

3. Evaluation of alternatives

4. Purchase Decision.

5. Postpurchase Behavior.

\section{Customer Satisfaction}

According to Tjiptono (2015), the word satisfaction comes from the Latin satis which means good enough, adequate, and facio means doing or making, so simply means it is an effort to fulfill something.

According to Tjiptono (2015), some of the benefits a company can get if it can maximize the level of customer satisfaction are as follows:

1. The existence of a long-term relationship between customers and the company

2. Establish a business growth opportunity from re-purchase, up-selling and cross-selling.

3. There is customer loyalty.

4. Make positive word of mouth references, so that they have the potential to get new customers and this will benefit the company.

5. Customer perceptions and company reputation become more positive in the view of customers.

6. Can increase company profits.

The factors that affect customer satisfaction according to Jasfar (2012), various factors can affect customer satisfaction, as follows:

1. Aspects of goods and services.

2. The emotional aspect of the customer.

3. Aspects of the influence of success or failure of services.

4. Perceptual aspects of equality or fairness.

5. Other customers, family, and co-workers. 


\section{Conseptual Framework}

Based on existing theoretical foundations and references from previous studies, therefore we can compile a theoretical framework, between security perceptions (X1), ease of transaction (X2), shopping experience (X3), Purchasing Decisions (Z), and Customer Satisfaction (Y).

\section{Figure 1 : Conseptual Framework}

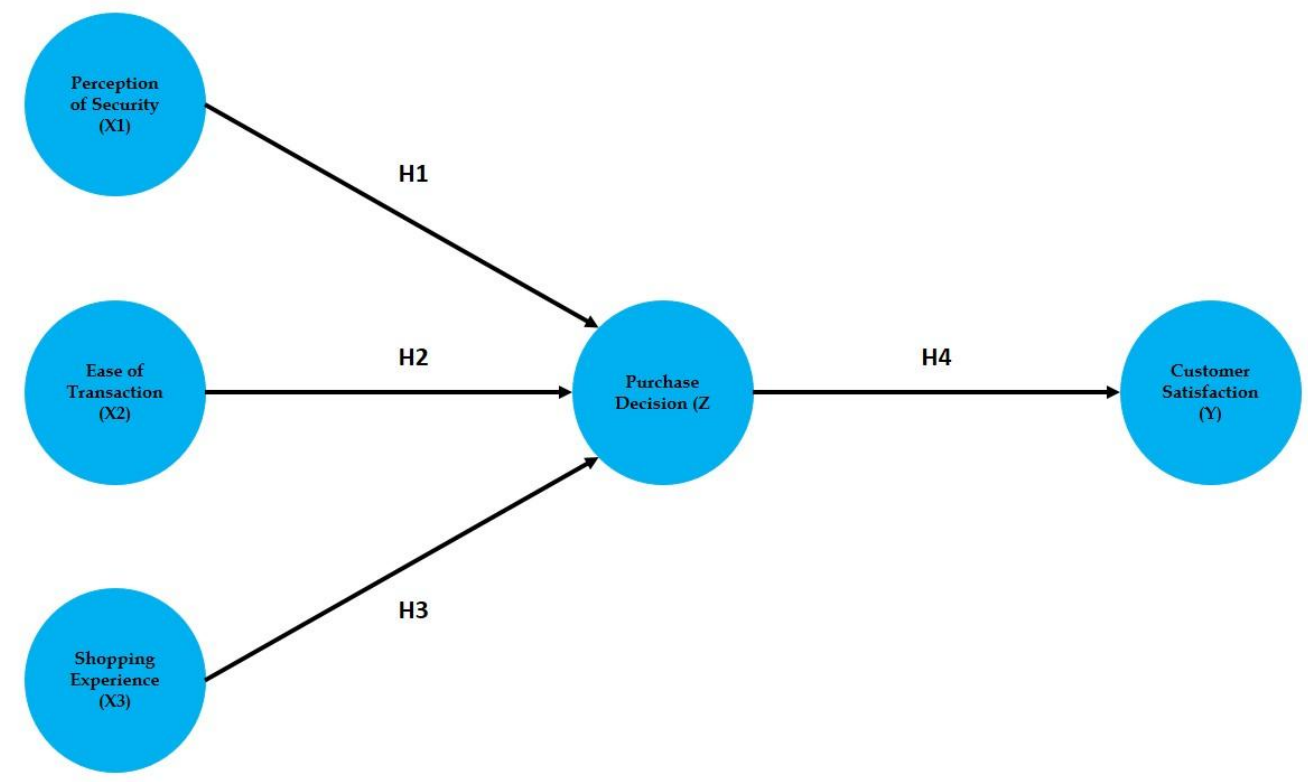

\section{Hypothesis}

Based on some of the results of previous studies, a research hypothesis can be formulated, namely the effect of perceived security (X1), ease of transaction (X2), shopping experience (X3) on purchasing decisions (Z), and the implications for customer satisfaction $(\mathrm{Y})$, development. the hypothesis can be explained as follows :

1. H1: There is no positive and significant effect between security on purchasing decisions.

2. H2: There is a positive and significant influence between ease of online purchasing decisions.

3. H3: There is a positive and significant influence between experience on online purchasing decisions.

4. H4: There is a positive and significant influence between purchasing decisions on online customer satisfaction.

\section{RESEARCH METHODS}

\section{Research Paradigm}

This study, using questions to Geraipedia customers with the help of a questionnaire. This study using qualitative data and processing the qualitative data into SMART PLS. 


\section{Population and Sample}

According to Supranto (2016) population is a group of the same elements, but can be distinguished from one another because of their characteristics. The differences are due to the different characteristic values. The population in this study includes all customers who have used the Geraipedia application in the Jakarta, Bogor, Depok, Tangerang, and Bekasi (Jabodetabek) areas.

According to Sekaran, Uma dan Roger Bougie (2017), the sample (sample) is a part of the population and consists of several members selected from the population. The sample in this study was as customers who have used the Geraipedia application, around Jakarta and Tangerang, totaling 100 samples.

\section{Operational Variables}

The operational variables of this study were classified as follows:

\section{Table 1 : Operational Variables}

\begin{tabular}{|c|c|c|c|}
\hline No & Variable & Definition & Indicator \\
\hline 1 & $\begin{array}{l}\text { Perception } \\
\text { of Security } \\
(\mathrm{X} 1)\end{array}$ & $\begin{array}{l}\text { Security perception is the ability of } \\
\text { online shops to chat and safeguard } \\
\text { data transactions. (Raman Arasu } \\
\text { and Viswanathan, 2011) }\end{array}$ & $\begin{array}{l}\text { a. Security } \\
\text { guarantee } \\
\text { b. Data } \\
\text { confidentiality }\end{array}$ \\
\hline 2 & $\begin{array}{l}\text { Ease of } \\
\text { Transaction } \\
(\mathrm{X} 2)\end{array}$ & $\begin{array}{l}\text { Ease of transaction is someone } \\
\text { believes that using technology will } \\
\text { be free of effort. The perception of } \\
\text { ease is a person's belief in using } \\
\text { technology that can be easily used } \\
\text { and understood (Tjini and } \\
\text { Baridwan, 2011) }\end{array}$ & $\begin{array}{l}\text { a. Easy to learn } \\
\text { b. Controllable } \\
\text { c. Clear and } \\
\text { understandable } \\
\text { d. Flexible } \\
\text { e. Easy to become } \\
\text { skillful } \\
\text { f. Easy to use }\end{array}$ \\
\hline 3 & $\begin{array}{l}\text { Shopping } \\
\text { Experience } \\
(\times 3)\end{array}$ & $\begin{array}{l}\text { Experience is learning that affects a } \\
\text { person's behavior change including } \\
\text { customer experience, information, } \\
\text { transaction experience. The term } \\
\text { experience has been used in several } \\
\text { ways (Kotler and Keller, 2016) }\end{array}$ & $\begin{array}{l}\text { a. Satisfied with } \\
\text { previous online } \\
\text { shopping } \\
\text { experiences. } \\
\text { b. Happy with the } \\
\text { previous online } \\
\text { shopping } \\
\text { experience. } \\
\text { c. Share your } \\
\text { shopping on } \\
\text { experience on } \\
\text { online buying } \\
\text { and selling sites } \\
\text { with friends }\end{array}$ \\
\hline
\end{tabular}




\begin{tabular}{|c|c|c|c|}
\hline 4 & $\begin{array}{l}\text { Purchase } \\
\text { Decision }(Z)\end{array}$ & $\begin{array}{l}\text { Purchasing decisions are making } \\
\text { decisions about purchases, which } \\
\text { include determining what to buy or } \\
\text { not to make purchases, which } \\
\text { decisions are based on the results } \\
\text { obtained from previous activities } \\
\text { (Assauri, 2017) }\end{array}$ & $\begin{array}{l}\text { a. Stability on a } \\
\text { product. } \\
\text { b. Habits in buying } \\
\text { products. } \\
\text { c. Provide } \\
\text { recommendations } \\
\text { to others. } \\
\text { d. Make repeat } \\
\text { purchases. }\end{array}$ \\
\hline 5 & $\begin{array}{l}\text { Customer } \\
\text { Satisfaction } \\
\text { (Y) }\end{array}$ & $\begin{array}{l}\text { Customer satisfaction is a person's } \\
\text { perception of the performance of a } \\
\text { product or service that is felt } \\
\text { compared to the expectations of the } \\
\text { customer, where customer } \\
\text { satisfaction will lead to brand } \\
\text { loyalty (Kottler, 2003). }\end{array}$ & $\begin{array}{l}\text { a. Customer } \\
\text { complaint and } \\
\text { suggestion } \\
\text { handling system } \\
\text { b. Company } \\
\text { reputation survey } \\
\text { system. } \\
\text { c. Customer } \\
\text { analysis system }\end{array}$ \\
\hline
\end{tabular}

ANALYSIS AND DISCUSSION

Outer Model

Convergent Validity and Discriminant Reliabilty Test $\mathbf{R}$

Table 2 : Loading Factor

\begin{tabular}{|l|r|r|}
\hline \multirow{4}{*}{ Variable } & Item & Value Loading \\
\hline \multirow{4}{*}{ Perception of Security (X1) } & PK1 & 0,859 \\
\cline { 2 - 3 } & PK2 & 0,910 \\
\cline { 2 - 3 } & PK3 & 0,875 \\
\cline { 2 - 3 } & PK4 & 0,796 \\
\cline { 2 - 3 } & PK5 & 0,855 \\
\cline { 2 - 3 } & PK6 & 0,856 \\
\cline { 2 - 3 } & PK7 & 0,840 \\
\hline Ease of Transaction (X2) & KT1 & 0,802 \\
\cline { 2 - 3 } & KT2 & 0,873 \\
\cline { 2 - 3 } & KT3 & 0,796 \\
\cline { 2 - 3 } & KT4 & 0,899 \\
\cline { 2 - 3 } & KT5 & 0,808 \\
\cline { 2 - 3 } & KT6 & 0,827 \\
\cline { 2 - 3 } & KT7 & 0,872 \\
\hline Shopping Experience (X3) & PB1 & 0,808 \\
\cline { 2 - 3 } & PB2 & 0,840 \\
\cline { 2 - 3 } & PB3 & 0,846 \\
\cline { 2 - 3 } & PB4 & 0,773 \\
\cline { 2 - 3 } & PB5 & 0,902 \\
\cline { 2 - 3 } & KP1 & 0,838 \\
\cline { 2 - 3 } & KP2 & 0,912 \\
\hline Purchase Decision (Z) & & \\
\hline
\end{tabular}




\begin{tabular}{|l|r|r|}
\hline \multirow{4}{*}{ Customer Satisfaction (Y) } & KP3 & 0,827 \\
\cline { 2 - 3 } & KP4 & 0,842 \\
\cline { 2 - 3 } & KP31 & 0,816 \\
\cline { 2 - 3 } & KP32 & 0,797 \\
\cline { 2 - 3 } & KP33 & 0,850 \\
\cline { 2 - 3 } & KP34 & 0909 \\
\cline { 2 - 3 } & KP35 & 0,869 \\
\cline { 2 - 3 } & KP36 & 0,731 \\
\cline { 2 - 3 } & KP37 & 0,737 \\
\hline
\end{tabular}

\section{Source: Smart PLS Data Processing Results (2020)}

The validity of the convergence is seen from the loading factor value for each indicator. According to Hair et al (2017), the loading factor parameter with a rule of thumb $>0.7$ is considered to meet the convergent validity requirements. The research data above shows that the loading factor has a value above 0.7 . So it can be said that the research data is valid.

Table 3 : Cross Loading

\begin{tabular}{|c|c|c|c|c|c|c|}
\hline Variable & Item & PK & KT & PB & KP & KPN \\
\hline \multirow{7}{*}{ Perception of Security (X1) } & PK1 & 0,859 & 0,402 & 0,495 & 0,402 & 0,473 \\
\hline & PK2 & 0,910 & 0,480 & 0,566 & 0,482 & 0,528 \\
\hline & PK3 & 0,875 & 0,425 & 0,476 & 0,475 & 0,435 \\
\hline & PK4 & 0,796 & 0,610 & 0,542 & 0,518 & 0,462 \\
\hline & PK5 & 0,855 & 0,495 & 0,500 & 0,473 & 0,440 \\
\hline & PK6 & 0,856 & 0,291 & 0,495 & 0,457 & 0,336 \\
\hline & PK7 & 0,840 & 0,313 & 0,393 & 0,389 & 0,393 \\
\hline \multirow[t]{7}{*}{ Ease of Transaction (X2) } & KT1 & 0,437 & 0,802 & 0,464 & 0,516 & 0,594 \\
\hline & KT2 & 0,466 & 0,873 & 0,563 & 0,591 & 0,673 \\
\hline & KT3 & 0,308 & 0,796 & 0,392 & 0,515 & 0,595 \\
\hline & KT4 & 0,499 & 0,899 & 0,622 & 0,634 & 0,666 \\
\hline & KT5 & 0,344 & 0,808 & 0,568 & 0,665 & 0,608 \\
\hline & KT6 & 0,455 & 0,827 & 0,543 & 0,620 & 0,678 \\
\hline & KT7 & 0,498 & 0,872 & 0,570 & 0,644 & 0,689 \\
\hline \multirow[t]{5}{*}{ Shopping Experience (X3) } & PB1 & 0,476 & 0,571 & 0,808 & 0,538 & 0,675 \\
\hline & PB2 & 0,427 & 0,549 & 0,840 & 0,526 & 0,624 \\
\hline & PB3 & 0,514 & 0,458 & 0,846 & 0,614 & 0,642 \\
\hline & PB4 & 0,501 & 0,462 & 0,773 & 0,492 & 0,610 \\
\hline & PB5 & 0,514 & 0,601 & 0,902 & 0,671 & 0,761 \\
\hline \multirow[t]{4}{*}{ Purchase Decision (Z) } & KP1 & 0,463 & 0,570 & 0,697 & 0,838 & 0,617 \\
\hline & KP2 & 0,468 & 0,677 & 0,701 & 0,912 & 0,672 \\
\hline & KP3 & 0,403 & 0,622 & 0,646 & 0,827 & 0,656 \\
\hline & KP4 & 0,353 & 0,724 & 0,678 & 0,842 & 0,592 \\
\hline Customer Satisfaction (Y) & KP31 & 0,421 & 0,721 & 0,526 & 0,674 & 0,816 \\
\hline
\end{tabular}




\begin{tabular}{|l|l|l|l|l|l|} 
KP32 & 0,422 & 0,753 & 0,513 & 0,604 & 0,797 \\
\hline KP33 & 0,422 & 0,556 & 0,537 & 0,641 & 0,850 \\
\hline KP34 & 0,429 & 0,573 & 0,609 & 0,666 & 0,909 \\
\hline KP35 & 0,466 & 0,617 & 0,629 & 0,683 & 0,869 \\
\hline KP36 & 0,391 & 0,446 & 0,575 & 0,539 & 0,731 \\
\hline KP37 & 0,543 & 0,375 & 0,534 & 0,528 & 0,737 \\
\hline
\end{tabular}

Source: Smart PLS Data Processing Results (2020)

From the data in table 4.2, the discriminant validity test was also carried out by looking at the value of cross-loadings. The cross-loading value of each construct is evaluated to ensure that the correlation of the construct with the measurement item is greater than that of other constructs. It can be seen that the cross-loading value greater than 0.7 can be said to be valid, and the research data can be said to be valid

Table 4 : Discriminant Validity

\begin{tabular}{|l|r|r|r|r|r|}
\hline & $\begin{array}{l}\text { Ease of } \\
\text { Transaction }\end{array}$ & $\begin{array}{l}\text { Customer } \\
\text { Satisfaction }\end{array}$ & $\begin{array}{l}\text { Purchase } \\
\text { Decision }\end{array}$ & $\begin{array}{l}\text { Shopping } \\
\text { Experience }\end{array}$ & $\begin{array}{l}\text { Perception } \\
\text { of Security }\end{array}$ \\
\hline $\begin{array}{l}\text { Ease of } \\
\text { Transaction }\end{array}$ & 0,840 & & & & \\
\hline $\begin{array}{l}\text { Customer } \\
\text { Satisfaction }\end{array}$ & 0,713 & 0,818 & & & \\
\hline $\begin{array}{l}\text { Purchase } \\
\text { Decision }\end{array}$ & 0,767 & 0,761 & 0,862 & & \\
\hline $\begin{array}{l}\text { Shopping } \\
\text { Experience }\end{array}$ & 0,636 & 0,684 & 0,797 & 0,835 & \\
\hline $\begin{array}{l}\text { Perception } \\
\text { of Security }\end{array}$ & 0,515 & 0,537 & 0,516 & 0,584 & 0,856 \\
\hline
\end{tabular}

Source: SmartPLS Data Processing Results (2020)

From the data in table 4.3, the discriminant validity test is also carried out by looking at the value of the discriminant validity. The value of discriminant validity in this study is seen from the root parameter value of Average Variance Extracted (AVE) and the correlation of latent variables with the rule of thumb of the root of Average Variance Extracted $(\mathrm{AVE})>$ correlation of latent variables. And the second is seen from the value of the cross loading parameter with the rule of thumbs $>0.7$, then by fulfilling these conditions, the research will be declared valid.

Table 5 : Average Variance Extracted (AVE) Value Results

\begin{tabular}{|l|r|}
\hline \multicolumn{1}{|c|}{ Variable } & \multicolumn{2}{c|}{$\begin{array}{c}\text { Average Variance Extracted } \\
\text { (AVE) }\end{array}$} \\
\hline Perception of Security & 0,733 \\
\hline Ease of Transaction & 0,706 \\
\hline Shopping Experience & 0,697 \\
\hline Purchase Decision & 0,742 \\
\hline Customer Satisfaction & 0,669 \\
\hline
\end{tabular}

Source: SmartPLS Data Processing Results (2020) 
The results of this study obtained the Average Variance Extracted (AVE) value of all variables above 0.5 . This means that the research conducted has met the validity requirements of the convergent test. This is following the opinion according to Ghozali and Latan (2015). The convergent validity of a construct with a reflective indicator is evaluated with an Average Variance Extracted (AVE) value which should be equal to 0.5 or more.

Table 6 : Composite Reliability

\begin{tabular}{|l|r|}
\hline \multicolumn{1}{|c|}{ Variable } & Composite Reliability \\
\hline Perception of Security & 0,951 \\
\hline Ease of Transaction & 0,944 \\
\hline Shopping Experience & 0,920 \\
\hline Purchase Decision & 0,935 \\
\hline Customer Satisfaction & 0,934 \\
\hline
\end{tabular}

Source: Smart PLS Data Processing Results (2020)

From the research above, it is obtained the value of the composite reliability above, it is concluded that the variables carried out in the study are said to be reliable with composite reliability above 0.7 , so they are considered to have good reliability (Ghozali and Latan, 2015). From table 4.3, it can be seen that the composite reliability value is above 0.7 , so all variables in this study are said to be reliable.

Table 7 : Cronbach's Alpha

\begin{tabular}{|l|r|}
\hline \multicolumn{1}{|c|}{ Variable } & Cronbach's Alpha \\
\hline Perception of Security & 0,939 \\
\hline Ease of Transaction & 0,930 \\
\hline Shopping Experience & 0,891 \\
\hline Purchase Decision & 0,913 \\
\hline Customer Satisfaction & 0,917 \\
\hline
\end{tabular}

Source: SmartPLS Data Processing Results (2020)

From this study, in addition to the composite reliability value, it can also be seen from the expected Cronbach's alpha value that is above 0.7 so it can be said to be reliable (Ghozali and Latan, 2015). From table 4.4, it can be seen that the value of composite reliability and Cronbach's alpha is above 0.7 , so all variables in this study are said to be reliable. Tables 4.3 and 4.4 can describe the research conducted that the variables used can be trusted.

\section{Inner Model}

Table 8 : R-square Coeffcients

\begin{tabular}{|c|c|}
\hline Variable & R-square \\
\hline Purchase Decision $(\mathrm{Z})$ & 0,749 \\
\hline Customer Satisfaction $(\mathrm{Y})$ & 0,579 \\
\hline
\end{tabular}

Source: Smart PLS Data Processing Results (2020) 
In the table, it is shown that the R-square value of Purchase Decisions $(Z)=0.749$ $=74.9 \%$, this means that the variables of perception of security, ease of transaction, and shopping experience jointly affect the purchasing decision variable by $74.9 \%$ and the remaining $25,1 \%$ is influenced by other variables not studied. While the R-square value of Customer Satisfaction $=0.579=57.9 \%$, this means that the purchasing decision variable affects the customer satisfaction variable by $57.9 \%$ and the remaining $42.1 \%$ is influenced by other variables not examined.

\section{Q-Square test}

$$
\begin{aligned}
\text { Q-Square } & =1-[(1-Z) \times(1-Y)] \\
& =1-[(1-0,749) \times(1-0,579)] \\
& =1-(0,106) \\
& =0,894
\end{aligned}
$$

The results of the calculation of the Q-square formula obtained a value of 0.894 or $89.4 \%$. Thus the data of this study explain as much as $89.4 \%$ and the remaining $10.6 \%$ are other factors that are not related to the research conducted.

\section{T-test}

In PLS-SEM, a test between the relationship has been carried out using a simulation with the bootstrapping method in the sample of this study. The t-test was carried out to determine the effect of each independent variable on the dependent variable partially. In Figure 4.6, you can see the results of the bootstrapping method testing, as follows:

\section{Figure 2 : Bootstrapping Model}

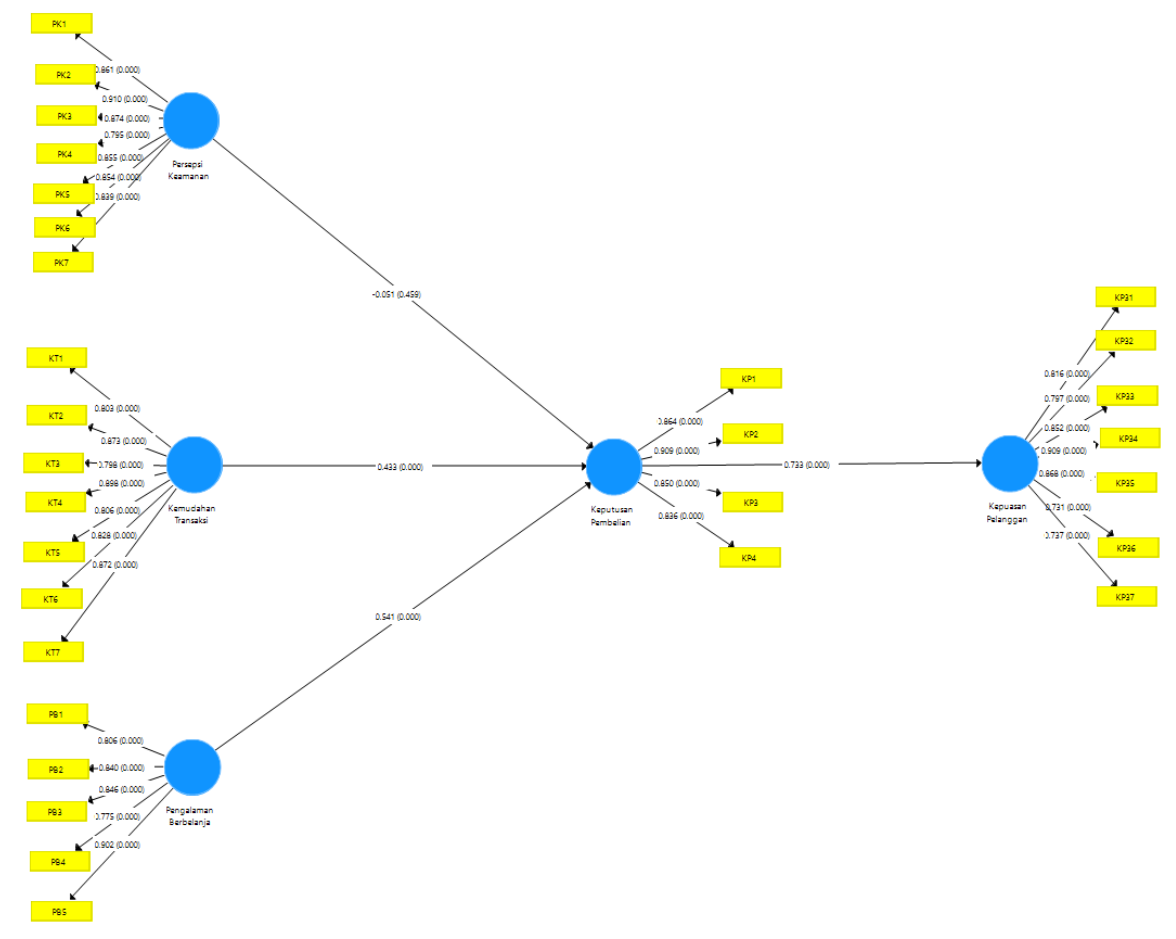

Source: Smart PLS Data Processing Results (2020) 
Hypothesis testing looks at the significance and strength of the relationship between construct variables in this study.

Table 9 : Path Coefficient

\begin{tabular}{|l|r|r|r|r|r|}
\hline & $\begin{array}{c}\text { Original } \\
\text { Sample } \\
\text { (O) }\end{array}$ & $\begin{array}{c}\text { Sample } \\
\text { Mean } \\
\text { (M) }\end{array}$ & $\begin{array}{r}\text { Standard } \\
\text { Deviation } \\
\text { (STDEV) }\end{array}$ & $\begin{array}{c}\mathbf{t} \text { - } \\
\text { Statistic }\end{array}$ & P-Values \\
\hline $\begin{array}{l}\text { Perception of Security } \\
\rightarrow \text { Purchase Decision }\end{array}$ & $-0,020$ & $-0,019$ & 0,062 & 0,318 & 0,750 \\
\hline $\begin{array}{l}\text { Ease of Transaction } \rightarrow \\
\text { Purchase Decision }\end{array}$ & 0,443 & 0,445 & 0,076 & 5,843 & 0,000 \\
\hline $\begin{array}{l}\text { Shopping Experience } \\
\rightarrow \text { Purchase Decision }\end{array}$ & 0,527 & 0,524 & 0,067 & 7,898 & 0,000 \\
\hline $\begin{array}{l}\text { Purchase Decision } \rightarrow \\
\text { Customer Satisfaction }\end{array}$ & 0,761 & 0,764 & 0,062 & 12,197 & 0,000 \\
\hline
\end{tabular}

Source: Smart PLS Data Processing Results (2020)

From the Smart PLS calculation, it can be seen that there is an influence or no effect. It can be said to have a positive or negative effect if the $t$-statistic value is $>1.96$ and it can be said that there is no positive or negative influence if the t-statistic is $<1.96$.

\section{Hypothesis Test}

Measuring the hypothesis by being able to make comparisons between the $t$ table and t-statistic values. The probability value, the $\mathrm{p}$-value with $5 \%$ alpha is $<0.05$, the $\mathrm{t}$-table value of $5 \%$ alpha is 1.96 If the t-statistic value is higher than the $t$-table value, it means that the hypothesis is accepted, and vice versa if the t-statistic value is lower than $\mathrm{t}$-table, meaning that the hypothesis is rejected. This study tested four existing hypotheses, as follows:

1. First Hypothesis

The first hypothesis is to test the effect of perceived security on purchasing decisions at Geraipedia, with the following hypothesis:

H0: Perception of security (X1) does not affect purchasing decisions (Z)

H1: Perception of security (X1) influences purchasing decisions (Z).

Based on table 4.6 , the security perception variable has no effect on the purchasing decision variable with a t-statistic of $0.318<1.96$, with a significance value of $0.750>$ 0.05. Thus, H0 is accepted and H1 is rejected. So the first hypothesis is rejected, meaning that security perceptions do not influence purchasing decisions.

2. Second Hypothesis

The second hypothesis tests the effect of ease of transaction on purchasing decisions at Geraipedia, with the following hypothesis:

$\mathrm{H0}$ : Ease of transaction (X2) does not affect purchasing decisions (Z).

$\mathrm{H} 1$ : Ease of transaction (X2) influences purchasing decisions $(Z)$.

Based on table 4.6, the transaction ease variable has an effect on the purchasing decision variable with a t-statistic of 5.843> 1.96, with a significance value of 0.00 $<0.05$. Thus $\mathrm{H} 0$ is rejected and H1 is accepted. So the second hypothesis is accepted, 
meaning that ease of transaction has a positive and significant effect on purchasing decisions.

3. Third Hypothesis

The third hypothesis tests the effect of shopping experience on purchasing decisions at Geraipedia, with the following hypothesis:

H0: Ease of transaction (X3) does not affect purchasing decisions (Z)

$\mathrm{H1}$ : Ease of transaction (X3) influences purchasing decisions (Z).

Based on table 4.6, the shopping experience variable has a positive effect to the purchasing decision variable with $t$-statistic $7,898>1.96$, with a significance value of $0.00<0.05$. Thus $\mathrm{H} 0$ is rejected and H1 is accepted. So the third hypothesis is accepted, meaning that the shopping experience has a positive and significant effect on purchasing decisions.

4. Fourth Hypothesis

The fourth hypothesis tests the effect of purchasing decisions on customer satisfaction at Geraipedia, with the following hypothesis:

H0: The purchase decision $(Z)$ does not affect customer satisfaction $(Y)$.

$\mathrm{H} 1$ : The purchase decision $(\mathrm{Z})$ influences customer satisfaction $(\mathrm{Y})$.

Based on table 4.6, the purchasing decision variable has an influence on the customer satisfaction variable with a t-statistic of 12.197> 1.96, with a significance value of $0.00<0.05$. Thus $\mathrm{H} 0$ is rejected and $\mathrm{H} 1$ is accepted. So the fourth hypothesis is accepted, meaning that purchasing decisions influence purchasing decisions.

\section{CONCLUSION}

Based on the research conducted, the following conclusions were obtained:

1. Perception of security does not influence purchasing decisions. So it can be said, a high or low level of security will not affect the purchasing decisions of Geraipedia customers.

2. Ease of transaction has a positive and significant effect on purchasing decisions. So it can be said that the easier transaction services at Geraipedia will increase purchasing decisions for Geraipedia customers.

3. Shopping experience has a positive and significant influence on purchasing decisions. So it can be said that the more customers have a good shopping experience, this will lead to an increase in purchasing decisions at Geraipedia.

4. Purchasing decisions influence customer satisfaction. So it can be said that the purchasing decisions of Geraipedia customers are very influential to increase sales. So customer purchasing decisions are very influential on customer satisfaction at Geraipedia. 
PRIMANOMICS : JURNAL EKONOMI DAN BISNIS - VOL. 19. NO. 2 (2021)

Versi Online Tersedia di : https://jurnal.ubd.ac.id/index.php/ds

| 1412-632X (Cetak) | 2614-6789 (Online) |

\section{REFERENCE}

\section{Books}

Assauri, Sofjan. (2017). Manajemen Pemasaran: Dasar, Konsep \& Strategi. Jakarta: Rajawali Perss

Fandi, Tjiptono (2015). Strategi Pemasaran, Edisi Keempat. Yogyakarta : Andi Offset.

Ghozali, I dan Latan, H. (2015). Partial Least Square. Konsep, Metode, dan Aplikasi, BPFE Universitas Diponegoro, Semarang.

Hair et al. 2017. A Primer on Partial Lest Squares Structurual Equation Modeling (PLS-SEM) $2^{\text {th }}$ Edition. Los Angeles, London, New Delhi, Singapore, Washington DC, Melbourne : SAGE

Kotler, Philips dan Amstrong, Gary. (2018). Principles of Marketing. Global Edition. Pearson Kotler, Philip dan Keller, Kevin Lane. (2016).Marketing Management $15^{\text {th }}$ Edition. Pearson

Schmitt, B. (2010). Experience marketing: Concepts, frameworks and Consumer Insights. Foundations and Trends in Marketing. Columbia University : New York.

Supranto, J. (2016). Statistik Teori dan Aplikasi. Edisi kedelapan. Jilid 1. Jakarta: Penerbit Erlangga

Sekaran, Uma dan Roger Bougie (2017). Metodologi Penelitian untuk Bisnis. Edisi 6. Buku 1. Jakarta: Salemba Empat.

Sekaran, Uma dan Roger Bougie (2017). Metodologi Penelitian untuk Bisnis. Edisi 6. Buku 2. Jakarta: Salemba Empat.

\section{Journal}

Flavia'n, C. and M. Guinali'u (2006) 'Consumer Trust, Perceived Security and Privacy Policy Three Basic Elements of Loyalty to a Web Site', Journal Industrial Management \& Data Systems. 106 (5), pp. 601-620.

Fachrizi Alwafi, dan Rizal Hari Magnadi (2016) 'Pengaruh Persepsi Keamanan, Kemudahan Bertransaksi, Kepercayaan Terhadap Toko dan Pengalaman Berbelanja Terhadap Minat Beli Secara Online Pada Situs Jual Beli Tokopedia.com', Journal of Management,Volume 5, Hal 2.

Isnain Putra Baskara, Guruh Taufan Hariyadi, SE, M.Kom (2014) 'Analisis Pengaruh Kepercayaan, Keamanan, Kualitas Pelayanan dan Persepsi Akan Resiko Terhadap Keputusan Pembelian Melalui Situs Jejaring Sosial (Social Networking Websites) (Studi Pada Mahasiswa di Kota Semarang)' , Jurnal Manajemen Fakultas Ekonomi dan Bisnis.

Meryl Astin Nangin, Irma Rasita Gloria Barus, dan Soegeng Wahyoedi (2020) 'The Effect of Perceived Ease of Use, Security, and Promotion on Trust and Its Implications on Fintech Adoption' Journal of Consumer Sciences, Vol 2 No. 2, pp. 124-138.

Raman, Arasu., dan Viswanathan, A (2011) 'Web Services and e-Shopping Decisions: A Study on Malaysian e-Consumer', IJCA Special Issue on:Wireless Information Networks \& Business Information System, pp. 54-60.

Selvi Eka Sari, Djumali, dan Eny Kustiah (2019) 'Pengaruh Kepercayaan, Pengalaman Pembelian, dan Kemudahan terhadap Keputusan Pembelian Produk Secara Online', Jurnal Manajemen.

Herlina Nasution, Choirul Maksum, dan Derriawan (2018) 'Pengaruh Kualitas Pelayanan dan Harga terhadap Keputusan Pembelian Pelanggan Serta Dampaknya pada Kepuasan Pelanggan (Studi Kasus : Maskapai PT. Lion Air Jakarta)' , Jurnal Ekonomi Bisnis Manajemen Vol. 3 No.2. 
Tjini,dkk (2013) 'Pengaruh Kepercayaan, Persepsi Kegunaan, Persepsi Kemudahan, dan Persepsi Kenyamanan Terhadap Minat Penggunaan Sistem Internet Banking', Vol 1, No 2: Semester Genap 2012/2013.

\section{Website}

https://www.cnbcindonesia.com

https://www.detik.com

https://www.pelanggan digital.com 